\title{
PENGARUH MEDIA PREZI TERHADAP HASIL BELAJAR PRAKARYA DAN KEWIRAUSAHAAN SISWA KELAS X SMAN 4 SINGARAJA
}

\author{
K. Diva Palguna1, A. Adiarta ${ }^{2}$, G. Indrawan ${ }^{3}$ \\ 1,2Prodi Pendidikan Teknik Elektro,Universitas Pendidikan Ganesha, Singaraja \\ ${ }^{3}$ Prodi Teknik Elektronika, Universitas Pendidikan Ganesha, Singaraja \\ e-mail: dipal.mg04@gmail.com, agus.adiarta@gmail.com,gindrawan@undiksha.ac.id
}

\begin{abstract}
Abstrak
Tujuan penelitian ini adalah untuk mengetahui pengaruh media Prezi terhadap hasil belajar siswa kelas X pada mata pelajaran Prakarya dan Kewirausahaan di SMA N 4 Singaraja. Metode penelitian yang digunakan adalah quasi eksperimen dengan Post-test Only Control Group Design. Objek penelitian terdiri dari 1 kelas eksperimen dan 1 kelas kontrol. Metode pemilihan objek penelitian dengan teknik random sampling. Kelas sampel dalam penelitian ini, yaitu kelas X MIA 3 sebagai kelas eksperimen dan kelas X MIA 6 sebagai kelas kontrol. Untuk menguji hipotesis digunakan teknik Uji-t satu pihak. Hasil penelitian dengan menggunakan Uji-t satu pihak menunjukkan bahwa perbandingan hasil belajar kelas eksperimen yang menggunakan media pembelajaran Prezi lebih tinggi dibandingkan dengan kelas kontrol yang menggunakan media pembelajaran konvensional. Hal ini dilihat dari hasil Uji$t$ satu pihak dengan thitung $=7,015$ lebih besar dari tabel $=1,672$. Jadi media pembelajaran Prezi memberikan pengaruh yang positif pada hasil belajar Prakarya dan Kewirausahaan.
\end{abstract}

Kata kunci: media pembelajaran, prezi, hasil belajar

\begin{abstract}
The aim of this study was to know about the effect of Prezi media to the learning result off class $x$ students about a Craft and Entrepreneurship at SMA N 4 Singaraja. The research method used quasi experiment with Post-test only control group design. The research object were a class experiment and a class control. The research object selection used random sampling. The sample class of this research were X MIA 3 class as experiment class and X MIA 6 as the control class. To examine the hypothesis, one sided $t$-test used. The one sided $t$-test result showed that the study result of experiment class which used the media of Prezi higher than the class control which used the conventional media. It could be seen from one sided $t$-test result with $t_{\text {sum }}=7,015$ bigger than table $=1,672$. So, the Prezi media gave the positive effect to the study result of a Craft and Entrepreneurship subject.
\end{abstract}

Keywords: learning media, Prezi, learning result

\section{Pendahuluan}

Dalam Undang-Undang Sistem Pendidikan Nasional Nomor 20 Tahun 2003, bahwa Pendidikan adalah usaha sadar dan terencana untuk mewujudkan suasana belajar dan proses pembelajaran agar peserta didik secara aktif mengembangkan potensi dirinya untuk memiliki kekuatan spiritual keagamaan, pengendalian diri, kepribadian, kecerdasan akhlak mulia, serta keterampilan yang diperlukan dirinya, masyarakat, bangsa dan negara.

Banyak terdapat permasalahan pendidikan yang seharusnya mendapat perhatian lebih dari pemerintah, sekolah dan juga guru, karena hal ini dapat menyangkut hasil belajar dari peserta didik. Sebagai salah satu contoh masalah yang sering dialami guru dalam proses pembelajaran adalah pemilihan strategi mengajar yang tepat untuk peserta didik. Pemilihan strategi mengajar yang tepat merupakan langkah awal dari proses pembelajaran, apabila langkah awal yang diambil tidak tepat maka akan berdampak pada hasil belajar peserta didik. Oleh karena itu, tidak semua strategi pembelajaran sesuai dengan tujuan pembelajaran. Hal tersebut dikarenakan kemampuan peserta didik yang berbeda-beda dalam menerima materi pelajaran yang disampaikan oleh guru di kelas.

Jenjang Sekolah Menengah Atas atau yang biasa disingkat dengan SMA adalah jenjang pendidikan menengah formal di Indonesia, jenjang ini adalah lanjutan dari Sekolah Menengah 
Pertama (SMP). SMA tersebut ditempuh selama 3 tahun, dimulai dari kelas $X$ sampai dengan kelas XII. Berdasarkan Kurikulum 2013 pada SMA, terdapat beberapa mata pelajaran baru yang dimasukkan kedalam kurikulum tersebut, salah satunya adalah mata pelajaran Prakarya dan Kewirausahaan.

Dikarenakan pelajaran Prakarya dan Kewirausahaan terbilang masih baru dalam Kurikulum 2013, tidak banyak guru yang mengajar prakarya yang memiliki keterampilan yang sesuai dengan mata pelajaran serta menggunakan metode dan strategi pembelajaran yang tepat. Hal ini berdampak pada peserta didik yang kurang mengerti dengan materi yang diajarkan oleh guru. Dikarenakan kurang mengerti dengan materi yang diajarkan, menyebabkan peserta didik tersebut tidak tertarik dengan mata pelajaran Prakarya dan Kewirausahaan.

Mata pelajaran Prakarya dan Kewirausahaan masih terbilang baru diajarkan di SMA, khususnya di SMA N 4 Singaraja. Dari pengamatan penulis selama melaksanakan observasi, terlihat bahwa peserta didik SMA N 4 Singaraja masih belum terbiasa dan paham dengan konsep yang diajarkan pada mata pelajaran ini, sehingga masih banyak peserta didik yang bingung bahkan malas untuk mengikuti pelajaran.

Hal ini dapat berdampak pada hasil belajar peserta didik tersebut, dimana hasil prestasi belajar mereka menjadi kurang bagus dikarenakan peserta didik terlalu malas untuk memperhatikan materi yang diajarkan. Hal ini juga akan berdampak lebih buruk apabila metode mengajar yang diajarkan oleh guru juga kurang tepat diberikan kepada peserta didik. Pembelajaran Prakarya dan Kewirausahaan dapat dikatakan berhasil apabila prestasi belajar peserta didik mencapai Kriteria Ketuntasan Minimal (KKM) yang telah ditentukan pada mata pelajaran Prakarya dan Kewirausahaan.

Di SMA N 4 Singaraja terdapat 3 jurusan untuk kelas X, yaitu MIA (Matematika dan Ilmu Alam), ISS (IImu-IImu Sosial) dan IBB (IImu Bahasa dan Budaya). Dalam mata pelajaran Prakarya dan Kewirausahaan pada semester Ganjil untuk kelas X terdapat beberapa materi, yaitu Kerajinan, Budidaya, Rekayasa dan Pengolahan. Pada materi Rekayasa di dalamnya membahas tentang materi pembuatan produk elektronika sederhana dengan sumber arus DC. Peserta didik akan menghasilkan sebuah Produk Elektronika yang memiliki nilai jual. Selain membuat produk, peserta didik juga akan belajar tentang sumber arus, komponen elektronika dan cara memasarkan produk hasil karya mereka sendiri, sehingga peserta didik mampu memahami proses dari perencanaan pembuatan produk elektronika sederhana tersebut. Oleh karena itu, dibutuhkan sebuah media animasi yang interaktif sehingga peserta didik lebih mudah mengerti dan lebih tertarik untuk memperhatikan materi pelajaran dibandingkan hanya menulis di papan saja.

Berdasarkan observasi yang telah dilakukan pada bulan Juni sampai dengan Juli 2017 di SMA N 4 Singaraja, diperoleh informasi bahwa hasil belajar mata pelajaran Prakarya dan Kewirausahaan masih tergolong rendah dan peserta didik cenderung jenuh dan mengantuk di setiap jam pelajaran. Dalam materi tersebut, selain dibutuhkan penjelasan secara teoretis diperlukan juga sebuah visualisasi atau gambaran nyata yang dapat memperjelas pandangan peserta didik terhadap objek yang mereka pelajari. Selain itu, tingkat pemahaman dan daya serap setiap peserta didik juga berbeda-beda dan hal ini tergantung dari cara peserta didik tersebut merekam dan memahami informasi yang diberikan.

Hal penting yang dibutuhkan di sini adalah pemilihan media yang tepat untuk penyampaian informasi kepada para peserta didik. Pemilihan jenis media yang tepat dan sesuai, akan menambah minat peserta didik untuk lebih memperhatikan materi yang diberikan. Penggunaan media yang kurang tepat dengan kondisi peserta didik, akan menyebabkan tidak berfungsinya media secara optimal dalam pembelajaran, sehingga terjadi miss communication antara peserta didik dan guru. Dari pengaruh tersebut, guru dituntut mampu mengetahui kecenderungan ataupun gaya belajar peserta didik sehingga materi yang diajarkan lebih dimengerti oleh peserta didik. Masih banyak guru yang belum mampu secara tepat menentukan media pembelajaran untuk peserta didik, dan hal ini menyebabkan hasil belajar peserta didik menjadi kurang optimal. Dari sekian banyak jenis media pembelajaran yang berkembang, media pembelajaran berbasis Information Technology (IT) merupakan media pembelajaran yang paling sering dipilih dan digunakan oleh guru sekarang. 
Kurangnya pemahaman materi oleh peserta didik, dapat mempengaruhi hasil belajar mereka secara signifikan, hal ini dapat dilihat dari nilai Kriteria Ketuntasan Minimal pelajaran Prakarya dan Kewirausahaan di kelas X pada semester Ganjil di SMA N 4 Singaraja tahun ajaran 2017/2018, masih sangat rendah. Peserta didik dituntut untuk mencapai nilai KKM, namun banyak peserta didik di kelas belum mencapai nilai KKM tersebut. Penyebabnya selain masalah strategi dan metode belajar yang digunakan, rendahnya minat belajar peserta didik juga menjadi masalah yang serius dan berdampak pada prestasi belajar mereka. Pada dasarnya rendahnya prestasi belajar ini disebabkan oleh dua faktor, yaitu faktor intrinsik (dari dalam peserta didik) misalnya kesehatan jasmani, minat belajar, kecerdasan, motivasi belajar, bakat peserta didik, kemampuan kognitif dan sikap peserta didik terhadap mata pelajaran. Sementara faktor ekstrinsik (dari luar peserta didik) meliputi keluarga, lingkungan, kurikulum, metode mengajar, guru, media pembelajaran dan fasilitas penunjang pembelajaran, maka dari itu prestasi belajar yang baik harus didukung oleh komponen intrinsik dan ekstrinsik tersebut. Dari beberapa wawancara yang peneliti lakukan terhadap beberapa peserta didik kelas

$\mathrm{X}$, dapat diambil kesimpulan bahwa ketika guru mengajar teori kebanyakan menggunakan media pembelajaran konvensional seperti alat/peraga dan menulis di papan tulis. Hal seperti ini terasa sangat membosankan bagi peserta didik dan mereka berpendapat bahwa penggunaan media pembelajaran yang lebih interaktif, seperti menyelipkan video di dalamnya dirasa sangat menarik dan mampu memunculkan minat peserta didik untuk memperhatikan materi pelajaran.

Dari penjabaran diatas, salah satu faktor yang mempengaruhi hasil belajar adalah penggunaan media pembelajaran. Dengan adanya media pembelajaran proses pembelajaran menjadi lebih mudah bagi peserta didik dan juga guru karena media pembelajaran dapat mengatasi keterbatasan ruang dan waktu belajar. Penggunaan media pembelajaran ini juga akan berdampak baik pada minat peserta didik untuk memperhatikan pelajaran, sehingga diharapkan prestasi belajarnya nanti dapat lebih baik. Dengan perkembangan teknologi informasi yang sangat pesat dalam hal media pembelajaran, ada begitu banyak program untuk membuat media pembelajaran yang unik dan menarik. Untuk tutorial penggunaanya juga sudah banyak terdapat di internet, jadi kita tidak perlu susah untuk belajar lagi dari awal.

Salah satu program untuk pembuatan media pembelajaran adalah Prezi. Program ini dapat digunakan untuk membuat media pembelajaran yang interaktif dan juga dapat digabungkan dengan berbagai jenis gambar, grafis, video, text, suara ataupun animasi yang dapat menarik minat peserta didik. Media pembelajaran Prezi ini dapat dikembangkan sesuai dengan kebutuhan pengembang itu sendiri dengan menyesuaikan materi ajar yang akan diajarkan.

\section{Metode}

Jenis penelitian ini merupakan eksperimen semu, mengingat tidak semua variabel (gejala yang muncul) dan kondisi eksperimen dapat diatur dan dikontrol secara ketat maka penelitian ini dikategorikan sebagai eksperimen semu (quasi experiment). Penelitian ini akan mengkaji tentang pengaruh media pembelajaran Prezi terhadap hasil belajar Prakarya dan Kewirausahaan.

Desain yang digunakan dalam penelitian ini adalah The Posttest-Only Control Group Design yang bisa dilihat pada Tabel 1, dimana dalam rancangannya kelompok eksperimen akan diberikan perlakuan berupa pembelajaran dengan menggunakan media Prezi, sedangkan kelompok kontrol akan diberikan pembelajaran dengan menggunakan media konvensional.

Tabel 1. Desain penelitian

\begin{tabular}{ccc}
\hline Kelompok & Perlakuan & Posttest \\
\hline $\mathrm{X}$ & $\mathrm{X}$ & $\mathrm{O}_{1}$ \\
$\mathrm{~K}$ & - & $\mathrm{O}_{2}$ \\
\hline
\end{tabular}


Keterangan:

$\mathrm{E}=$ Eksperimen

$\mathrm{K}=$ Kontrol

$\mathrm{X}=$ Perlakuan dengan

Media Prezi $=$ Perlakuan dengan Media Konvensional, $\mathrm{O}_{1}=$ Pengamatan akhir hasil belajar kelas eksperimen, $\mathrm{O}_{2}=$ Pengamatan akhir hasil belajar kelas kontrol.

Tahapan pelaksanaan penelitian ini akan dibagi menjadi 3 , yaitu 1) tahap pengembangan media; 2) tahap persiapan penelitian; dan 3) tahap pelaksanaan penelitian. Dalam penelitian ini, populasi yang digunakan adalah peserta didik kelas X SMA N 4 Singaraja Jurusan MIA, tahun ajaran 2017/2018 yang saat ini mengikuti mata pelajaran Prakarya dan Kewirausahaan yang berjumlah 246 orang. Tabel distribusi populasi kelas X MIA bisa dilihat pada Tabel 2.

Tabel 2. Distribusi populasi penelitian

\begin{tabular}{ccc}
\hline No & Kelas & Jumlah Siswa \\
\hline 1 & X MIA 1 & 36 \\
2 & X MIA 2 & 35 \\
3 & X MIA 3 & 35 \\
4 & X MIA 4 & 35 \\
5 & X MIA 5 & 35 \\
6 & X MIA 6 & 35 \\
7 & X MIA 7 & 35 \\
\hline
\end{tabular}

Teknik yang digunakan untuk pengambilan sampel penelitian adalah teknik random sampling. Untuk meyakinkan bahwa populasi yang akan digunakan sebagai sampel setara, dilakukan uji kesetaraan menggunakan uji- $F$ atau ANAVA satu jalur. Data yang digunakan dalam uji ini adalah nilai hasil ulangan harian Prakarya dan Kewirausahaan.

Dari hasil uji kesetaraan, diperoleh $F_{\text {hitung }}=1,109$. Untuk taraf signifikansi $5 \%$ dengan $\mathrm{dk}$ pembilang $=6$ dan dk penyebut $=239$, diperoleh $F_{\text {tabel }}=2,136$. Karena $F_{\text {hitung }}<F_{\text {tabel, }}$, maka populasi tersebut dinyatakan setara.

Dikarenakan seluruh populasi dinyatakan setara, maka dilanjutkan pengundian untuk mencari kelas sampel dengan teknik random sampling. Dari hasil undian, didapatkan kelas $X$ MIA 3 sebagai kelas eksperimen dan kelas X MIA 6 sebagai kelas kontrol. Setyosari (2015) menyatakan bahwa, dalam sebuah penelitian salah satu faktor yang mempengaruhi hasil penelitian yang bersumber dari pelaksanaan penelitian itu sendiri adalah validitas internal. Terdapat 5 jenis validitas internal dimana validitas ini merupakan pengendalian perlakuan agar hasil yang diperoleh benar-benar berasal dari perlakuan yang diberikan.

a) Pengendalian Sejarah (history)

Pengendalian ini berfungsi agar tidak terjadi peristiwa lain saat pengambilan eksperimen di dalam kelas. Pertemuan dilaksanakan sebanyak 4 kali pada kelas eksperimen dan kelas kontrol, selain itu ruang kelas yang digunakan juga tidak berubah, yaitu pada ruang kelas masing-masing kelas kontrol dan eksperimen serta dilaksanakan pada jam pelajaran seperti biasanya.

b) Pengendalian Kematangan (maturity)

Pengendalian ini tertuju pada perubahan biologis dan psikologis yang sistematis pada objek dalam waktu tertentu. Pengendalian di sini dilihat dari umur pada peserta didik pada masing-masing kelas eksperimen dan kelas kontrol. Rata-rata untuk kedua kelas memiliki umur peserta didik yang sama, yaitu antara $17-18$ tahun sehingga dapat disimpulkan kedua kelas memiliki kematangan usia yang sama. 
c) Pengendalian Efek Tes

Efek tes dilakukan dengan membuat soal posttest, dimana posttest diberikan setelah treatment yang dilakukan pada masing-masing kelas sampel. Soal yang diberikan berbentuk pilihan ganda sejumlah 35 butir dengan waktu pengerjaan 45 menit dan pengawasan yang sama antara kelas eksperimen dan kelas kontrol.

d) Pengendalian Efek Regresi (regression)

Untuk mengatasi efek ini, jam pelajaran yang diberikan antara kelas eksperimen dan kelas kontrol sama, yaitu 2 jam pelajaran. Instrumen penelitian yang digunakan juga sudah diuji validitas dan reliabilitasnya.

e) Pengendalian Efek Mortality

Untuk mengendalikan efek ini, lama waktu yang digunakan dalam penelitian dibuat sesingkat mungkin agar tidak terjadi pengaruh yang besar pada hasil eksperimen. Dimana objek penelitian berupa peserta didik yang akan diambil hanya berjumlah 30 orang.

Validitas eksternal merupakan seberapa jauh suatu hasil penelitian dapat digeneralisasikan ke populasi pada situasi, waktu, dan objek yang berbeda. Validitas eksternal memiliki 3 faktor, yaitu validitas populasi, validitas ekologis dan validitas temporal, di sini akan digunakan validitas ekologis diantaranya:

a) Pengendalian Materi Pembelajaran

Materi pembelajaran yang akan diajarkan kepada kedua kelas adalah sama antara kelas kontrol maupun kelas eksperimen dengan materi yang sesuai dengan silabus dan RPP yang digunakan.

b) Pengendalian Guru Pengajar

Untuk mengantisipasi terjadinya perbedaan penyampaian materi pada kelas eksperimen dan kelas kontrol, maka materi akan diajarkan langsung oleh guru yang bersangkutan di kelas eksperimen dan kelas kontrol, sehingga terjadi kesamaan persepsi dalam penyampaian materi pelajaran.

c) Pengendalian Waktu Belajar

Dalam pengendalian ini waktu yang digunakan pada saat pembelajaran harus disamakan antara kelas eksperimen dan kelas kontrol. Waktu efektif yang digunakan adalah pagi hari dari jam 07.30 - 09.30 sehingga peserta didik masih dalam kondisi yang sama.

Dalam penelitian ini data yang hendak diambil adalah hasil belajar kognitif Prakarya dan Kewirausahaan, maka dari itu metode pengumpulan data yang digunakan adalah metode tes. Menurut Agung (2011), metode tes dalam kaitannya dengan penelitian adalah cara memperoleh data yang berbentuk suatu tugas yang dilakukan atau dikerjakan oleh seseorang atau sekelompok orang yang di tes (testee), dan dari tes tersebut dapat menghasilkan suatu data berupa skor (data interval).

Tes formatif yang digunakan dalam penelitian ini berbentuk pilihan ganda (objektif) yang berjumlah 50 butir soal. Dalam tes tersebut, terdiri dari pernyataan (pokok soal) dan alternatif jawaban yang mencakup kunci jawaban dan pengecoh (distractor). Soal yang dijawab benar bernilai 1 sedangkan soal yang dijawab salah bernilai 0 .

Tes ini meliputi beberapa indikator berdasarkan Standar Kompetensi/ Kompetensi Dasar yang berlaku di SMA N 4 Singaraja dalam mata pelajaran Prakarya dan Kewirausahaan.

Untuk menguji validitas isi dan validitas butir soal dilakukan dengan melakukan uji pakar pada tes tersebut dengan menggunakan rumus Gregory. Berdasarkan hasil uji tersebut, semua soal dianggap relevan oleh pakar dengan nilai kuantitatif yang diperoleh, yaitu 1,00 yang berada di kategori koefisien validitias sangat tinggi. Kemudian untuk validitas butor soal dicari menggunakan rumus koefisien korelasi point biserial ( $r_{\text {pbi }}$ ) sebagai berikut (Sudijono, 2013: 185).

Kriteria butir soal dinyatakan valid apabila $r_{\text {hitung }}>r_{\text {tabel }}$ dengan taraf signifikasi $5 \%$. Berdasarkan hasil analisis validitas butir soal yang dilakukan, dari 50 butir soal yang diujikan kepada 60 responden, diperoleh hasil 35 butir soal yang valid dan 15 butir tes yang drop.

Selanjutnya, 35 butir soal yang valid tersebut dilakukan uji reliabilitas untuk menguji 
keajegan atau ketepatan dan konsistensi suatu instrumen tes. Trianto (2010) menyebutkan bahwa, instrumen yang reliabel apabila instrumen tersebut konsisten atau ajek dalam hasil ukurnya sehingga dapat dipercaya. Rumus yang digunakan adalah Kuder Richardson (KR-20) sebagai berikut (Sudijono, 2013:254).

Kriteria terhadap koefisien reliabilitas tes $r_{11}$ digunakan patokan, yaitu (1) apabila $r_{11} \geq$ 0,70 berarti tes yang diuji reliabilitas dinyatakan reliabel; (2) apabila $r_{11} \leq 0,70$ berarti tes kompetensi yang sedang diuji reliabilitas dinyatakan unreliable. Berdasarkan hasil analisis perhitungan, maka diperoleh $r_{11}=0,84$ yang berarti bahwa tes objektif tipe pilihan ganda pada penelitian ini tergolong reliabel. Penelitian ini menggunakan dua buah variabel, yaitu variabel bebas (Independent Variable) dan variabel terikat (Dependent Variable). Variabel bebas dalam penelitian ini adalah media pembelajaran Prezi yang digunakan pada kelas eksperimen. Prezi merupakan media yang berbasis frame yang tersusun dalam sebuah kanvas besar. Prezi menggunakan teknik zoom-in dan zoom-out untuk perpindahan dari masing-masing frame, atau bisa juga disebut sebagai aplikasi Zooming User Interface (ZUI) seperti yang terlihat pada Gambar 1 berikut.

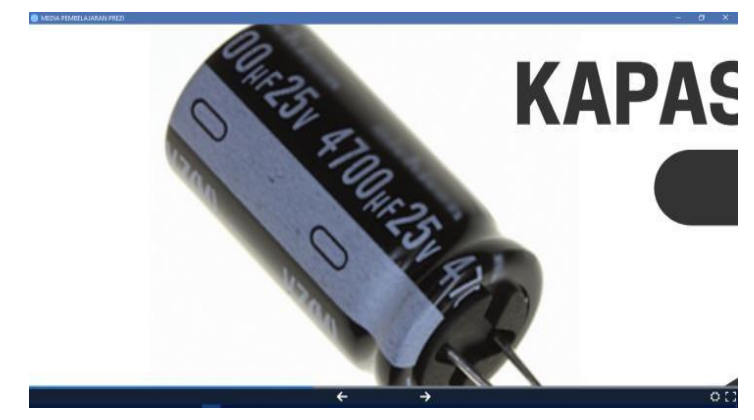

Gambar 1. Zooming User Interface (ZUI) pada Prezi

Frame dapat dianalogikan sebagai sebuah slide dalam PowerPoint. Aplikasi ini dapat dijalankan pada komputer atau laptop dengan cara menginstal Prezi Desktop. Kita juga dapat mengakses Prezi secara online pada perangkat smartphone atau komputer dengan mengunjungi situs www.Prezi.com dan login menggunakan akun yang kita buat, seperti terlihat pada Gambar 2, jadi sangat memudahkan untuk diakses dimana saja dan kapan saja.

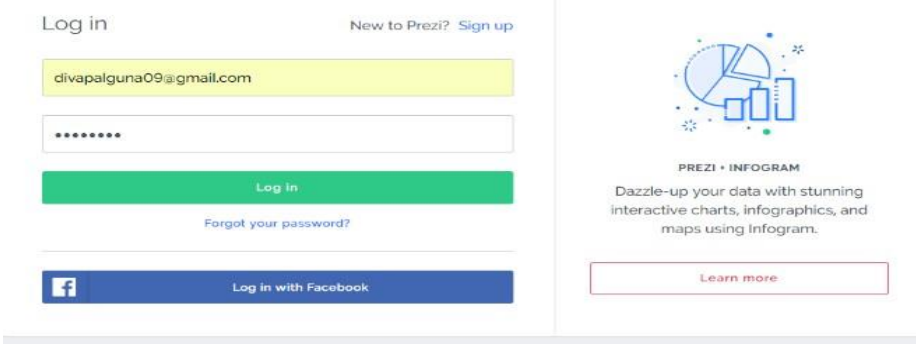

Gambar 2. Tampilan login Prezi

Variabel terikat dalam penelitian ini adalah hasil belajar Prakarya dan Kewirausahaan kelas sampel di SMA N 4 Singaraja. Hasil belajar merupakan seluruh kecakapan dan hasil yang dicapai oleh peserta didik melalui proses pembelajaran di sekolah. Hasil belajar tersebut dinyatakan dalam angka atau dalam bentuk nilai berdasarkan hasil tes yang sudah mereka lakukan sebelumnya. Dalam penelitian ini, hasil belajar menggunakan nilai posttest Prakarya dan Kewirausahaan peserta didik kelas X SMA N 4 Singaraja.

1) Teknik Analisis Data

Setelah kedua kelas sampel diberi perlakuan, selanjutnya dilakukan pengujian terhadap hipotesis yang diajukan. Data yang digunakan adalah data hasil posttest peserta didik yang diberikan kepada kedua kelas sampel. Sebelum dilakukan uji hipotesis, dilakukan uji prasyarat analisis terlebih dahulu yang mencakup pengujian normalitas sebaran data dan homogenitas varians. 
Pengujian normalitas sebaran data hasil belajar kelas sampel dilakukan untuk meyakinkan bahwa data hasil belajar dari kelas sampel terdistribusi normal. Data tersebut dianalisis dengan menggunakan teknik Lilliefors, dimana:

(1) Menampilkan data dengan urutan dari data yang terkecil sampai dengan data yang terbesar

(2) Menghitung frekuensi data

(3) Menghitung frekuensi data pada kurva normal dengan batas $Z \bar{y}$ yng dinyatakan dengan $F(Z)$ yakni luas daerah dibawah kurva normal pada jarak $Z$

(4) Menghitung frekuensi kumulatif data (FK)

(5) Menghitung probabilitas frekuensi kumulatif yang dinyatakan dengan $S(Z)$

(6) Menghitung harga mutlak selisih antara $F(Z)$ dengan $S(Z)$ yang dinyatakan dengan $F(Z)-S(Z)$

(7) Mencari nilai $|F(Z)-S(Z)|$ yang terbesar yang selanjutnya ditetapkan sebagai nilai Lhitung.

(8) Nilai $L_{\text {hitung }}$ dibandingkan dengan nilai $L_{\text {tabel }}$ yang diperoleh dari tabel Lilliefors.

(9) Apabila nilai $L_{\text {hitung }}$ kurang dari nilai $L_{\text {tabel }}$ maka hipotesis nol yang menyatakan data berasal dari populasi yang terdistribusi normal dapat diterima. (Candiasa, 2010b)

Uji homogenitas varians yang digunakan untuk kedua kelas sampel adalah uji- $F$. dengan rumus sebagai berikut sebagai berikut (Sugiyono, 2013: 140).

$$
F_{\text {hit }}=\frac{S_{1}^{2}}{S_{2}^{2}}
$$

Kriteria pengujian, jika $F_{\text {hitung }} \geq F_{\alpha(n 1-1, n 2-1)}$ maka varians data tidak homogen dan jika $F_{\text {hitung }}$ $<F_{\alpha(n 1-1, n 2-1)}$ maka varians data homogen. Pengujian ini dilakukan pada taraf signifikasi $5 \%$ dengan derajat kebebasan untuk pembilang $n_{1}-1$ dan derajat kebebasan untuk penyebut $n_{2}-1$.

2) Uji Hipotesis

Setelah melakukan prasyarat uji normalitas sebaran data dan homogenitas varians, maka dilanjutkan dengan menguji hipotesis nol $\left(H_{0}\right)$. Hipotesis statistiknya ditulis sebagai berikut:

$\mathrm{H}_{0}: \mu_{1} \leq \mu_{2}$ melawan $\mathrm{H}_{0}: \mu_{1}>\mu_{2}$

Jika sudah terbukti data hasil belajar kedua sampel terdistribusi normal dan memiliki varians yang homogen, maka digunakan rumus Uji-t separated varians sebagai berikut (Sugiyono, 2013: 138). Ketentuan dari uji ini adalah $t_{\text {hitung }}<\mathrm{t}_{\text {tabel }}$, maka $\mathrm{H}_{\mathrm{a}}$ ditolak, $\mathrm{H}_{0}$ diterima, sedangkan jika thitung $>t_{\text {tabel}}$, maka $\mathrm{H}_{\mathrm{a}}$ diterima, $\mathrm{H}_{0}$ ditolak. Dengan $\mathrm{t}_{\text {tabel }}$ didapat dari tabel distribusi $t$ pada taraf signifikasi $\alpha 5 \%$ dengan $\mathrm{dk}=\left(\mathrm{n}_{1}+\mathrm{n}_{2}-2\right)$.

\section{Hasil dan Pembahasan}

1) Deskripsi Data

Dari data yang sudah terkumpul, diperoleh rata-rata nilai untuk kelompok eksperimen adalah 88 dan rata-rata nilai untuk kelompok kontrol adalah 76,47. Untuk rangkuman analisis terhadap data hasil belajar Prakarya dan Kewirausahaan kelas eksperimen dan kelas kontrol disajikan pada Tabel 3. 
Tabel 3. Rangkuman analisis data

\begin{tabular}{lcc}
\hline \multicolumn{1}{c}{ Variabel } & $\begin{array}{c}\text { Kelas } \\
\text { Eksperimen }\end{array}$ & $\begin{array}{c}\text { Kelas } \\
\text { Kontrol }\end{array}$ \\
\hline Jumlah Siswa & 30 & 30 \\
Mean & 88 & 76,47 \\
Median & 90 & 77 \\
Modus & 91 & 80 \\
Std. Deviasi & 6,685 & 6,033 \\
Varians & 44,69 & 36,40 \\
Minimum & 77 & 66 \\
Maximum & 97 & 89 \\
\hline
\end{tabular}

Kelas eksperimen yang menggunakan media Prezi menunjukkan Lnitung $=0,1600$. Dengan taraf signifikasi $5 \%$ dan jumlah data $n=30$ didapatkan $L_{\text {tabel }}=0,1618$. Karena $L_{\text {nitung }}<$ $L_{\text {tabel, }}$ maka data hasil belajar kelas eksperimen dikatakan terdistribusi normal.

Sedangkan untuk kelas kontrol yang menggunakan media konvensional menunjukkan $L_{\text {hitung }}=0,1166$. Dengan taraf signifikasi $5 \%$ dan jumlah data $n=30$ didapatkan $L_{\text {tabel }}=0,1618$. Karena $L_{\text {hitung }}<L_{\text {tabel, }}$ maka data hasil belajar kelas eksperimen dikatakan terdistribusi normal. Untuk rangkuman hasil uji normalitas kelas sampel bisa dilihat pada Tabel 4.

Tabel 4. Rangkuman uji normalitas

\begin{tabular}{ccccc}
\hline Sampel & $n$ & $L_{\text {hitung }}$ & $L_{\text {tabel }}$ & Keterangan \\
\hline Eksperimen & 30 & 0,1600 & 0,1618 & normal \\
kontrol & 30 & 0,1166 & 0,1618 & normal \\
\hline
\end{tabular}

Setelah melakukan uji prasyarat normalitas sebaran data, kemudian dilanjutkan dengan melakukan uji homogenitas varians. Uji homogenitas dilakukan untuk menguji apakah kelas eksperimen dan kelas kontrol memiliki varians yang homogen atau tidak. Uji yang digunakan adalah Uji- $F$ dengan kriteria data homogen $F_{\text {hitung }}<\mathrm{F}_{\text {tabel }}$.

Dari hasil analisis, didapatkan $F_{\text {hitung }}$ dari data hasil belajar posttest kelas eksperimen dan kontrol adalah 1,1081, sedangkan $F_{\text {tabel }}$ dengan dk pembilang 29 dan dk penyebut 29 serta taraf signifikasi 0,05 adalah 1,8608. Jadi, $F_{\text {hit }}<F_{\text {tabel }}$ yang berarti varians data hasil belajar Prakarya dan Kewirausahaan kelas eksperimen dan kelas kontrol adalah homogen. Untuk rangkuman hasil perhitungan homogenitas varians kelas eksperimen dan kontrol, bisa dilihat pada Tabel 5.

Tabel 5. Rangkuman uji homogenitas

\begin{tabular}{cccc}
\hline Sumber data & $\mathrm{F}_{\text {hitung }}$ & $\mathrm{F}_{\text {tabel }}$ & Status \\
\hline $\begin{array}{c}\text { Kelas Eksperimen } \\
\text { dan Kontrol }\end{array}$ & 1,1081 & 1,8608 & Varians Homogen \\
\hline
\end{tabular}

Setelah kedua uji prasyarat dipenuhi, kemudian dilanjutkan dengan menguji hipotesis. Hipotesis yang akan diuji pada penelitian ini adalah, Hasil belajar antara kelompok peserta didik yang menggunakan media pembelajaran Prezi lebih tinggi daripada hasil belajar peserta didik yang menggunakan media konvensional.

Berdasarkan perhitungan uji prasyarat yang menunjukkan bahwa, data hasil belajar kelas sampel terdistribusi normal dan memiliki varians yang homogen, maka uji hipotesis 
dilanjutkan dengan menggunakan Uji-t separated varians. Ringkasan hasil uji-t pada penelitian ini bisa dilihat pada Tabel 6 .

Tabel 6. Ringkasan hasil uji hipotesis

\begin{tabular}{lcccccc}
\hline Kelas Sampel & $\mathrm{n}$ & $\Sigma \mathrm{X}$ & $\mathrm{S}^{2}$ & $\mathrm{~T}_{\text {hitung }}$ & $\mathrm{T}_{\text {tabel }}$ & Kesimpulan \\
\hline Eksperimen & 30 & 2640 & 44,69 & & & $\mathrm{H}_{\circ}$ ditolak \\
Kontrol & 30 & 2294 & 36,40 & & 1,672 & $\mathrm{H}_{\mathrm{a}}$ diterima \\
\hline
\end{tabular}

Dari hasil analisis diperoleh $t_{\text {hitung }}=7,015$. Dengan $\mathrm{dk}=58$ dan taraf signifikasi 0,05 didapatkan $t_{\text {tabel }}=1,672$, apabila dibandingkan, maka $t_{\text {hitung }}>t_{\text {tabel }}$ sehingga $H_{0}$ ditolak dan $\mathrm{H}_{a}$ diterima. Jadi, terdapat pengaruh yang signifikan penggunaan media pembelajaran Prezi terhadap hasil belajar Prakarya dan Kewirausahaan di kelas X di SMA N 4 Singaraja.

\section{2) Pembahasan}

Dari hasil analisis data terhadap data hasil belajar peserta didik kelas eksperimen yang menggunakan media pembelajaran Prezi, diketahui rata-rata skor yang dihasilkan adalah 88, dan rata-rata skor pada kelas kontrol yang menggunakan media pembelajaran konvensional adalah 76,47. Dari data tersebut, diketahui juga bahwa sebaran data dari kelas eksperimen dan kontrol terdistribusi normal dan memiliki varian yang homogen. Dikarenakan hasil $t_{\text {hitung }}>t_{\text {tabel }}$ maka $\mathrm{H}_{0}$ yang menyatakan bahwa hasil belajar kelompok peserta didik yang menggunakan media pembelajaran Prezi tidak lebih tinggi daripada hasil belajar peserta didik yang menggunakan media konvensional ditolak, dan $\mathrm{H}_{a}$ yang menyatakan hasil belajar kelompok peserta didik yang menggunakan media pembelajaran Prezi lebih tinggi daripada hasil belajar peserta didik yang menggunakan media konvensional dapat diterima. Penggunaan media pembelajaran merupakan hal yang baik dalam proses pembelajaran, namun juga harus dipertimbangkan dalam pemilihan jenis media pembelajaran yang akan digunakan agar sesuai dengan kondisi di lapangan, sehingga media pembelajaran yang digunakan menjadi lebih optimal. Penggunaan media pembelajaran yang tepat, dapat mempengaruhi hasil belajar dari peserta didik, media pembelajaran yang digunakan oleh guru harus disesuaikan dengan keadaan tempat dan kondisi siswa serta materi yang akan disampaikan.

Penggunaan media pembelajaran Prezi pada mata pelajaran Prakarya dan Kewirausahaan akan membuat peserta didik lebih tertarik untuk mengikuti pelajaran dikarenakan media ini merupakan hal yang baru bagi mereka. Dengan ketertarikan peserta didik dalam mengikuti proses pembelajaran, hal ini juga akan membantu peserta didik untuk menerima materi yang diajarkan oleh guru lewat media pembelajaran tersebut, sehingga hasil belajar yang dihasilkan juga meningkat.

Dalam proses pembelajaran menggunakan media pembelajaran Prezi, peserta didik menjadi lebih tertarik dengan materi yang disampaikan oleh guru, selain itu, media pembelajaran Prezi ini merupakan hal yang baru untuk mereka. Visualisasi materi pembelajaran menjadi lebih jelas, sebagian peserta didik yang sebelumnya kurang fokus untuk mengikuti pelajaran, menjadi lebih tertarik untuk mengikuti materi yang disampaikan melalui media pembelajaran ini. Hal ini tidak lepas dari kelebihan Prezi yang dapat menampilkan zoom-in dan zoom-out, pada gambar yang dimasukkan kedalam media pembelajaran ini. Selain itu, efek transisi antar frame yang juga menarik membuat siswa lebih antusias mengikuti proses pembelajaran yang dilakukan oleh guru.

\section{Simpulan dan Saran}

Berdasarkan hasil penelitian, dapat disimpulkan bahwa media pembelajaran Prezi berpengaruh pada hasil belajar peserta didik. Hal ini ditunjukkan dengan hasil posttest yang telah dianalisis, diperoleh $t_{\text {hitung }}>t_{\text {tabel }}$. Dengan demikian hasil belajar siswa yang menggunakan media 
pembelajaran Prezi lebih baik daripada hasil belajar siswa yang menggunakan media pembelajaran konvensional.

Dari hasil penelitian dan pembahasan, agar mampu mencapai hasil belajar dengan menggunakan media pembelajaran yang sesuai dengan yang diharapkan, saran yang dapat disampaikan adalah peneliti menyarankan agar pengujian media pembelajaran ini dilakukan pada satu atau lebih variabel terikat yang berbeda. Dalam penggunaan media pembelajaran, diharapkan guru paham dan mengerti tentang penggunaan media pembelajaran yang akan dipakai agar hasil yang dicapai menjadi maksimal. Diharapkan, peneliti lain mampu melakukan penelitian terhadap jumlah populasi yang lebih luas dan materi pembelajaran yang berbeda agar mampu melihat pengaruh dari penggunaan media pembelajaran ini lebih dalam. Kepada guru mata pelajaran Prakarya dan Kewirausahaan, diharapkan dapat menerapkan media pembelajaran Prezi sebagai salah satu alternatif dalam pilihan penggunaan media pembelajaran, mengingat pengaruh positif yang dihasilkan dari penggunaan media pembelajaran ini dalam proses pembelajaran di dalam kelas. Bagi peneliti lain, diharapkan perencanaan dalam penelitian selanjutnya, lebih baik dilaksanakan dalam waktu dan porsi yang lebih matang, sehinggafaktorfaktor dan hambatan dalam penelitian ini dapat dikurangi.

\section{DAFTAR PUSTAKA}

Agung, A. A. Gede. 2011. Metodologi Penelitian Pendidikan. Singaraja: Fakultas Ilmu Pendidikan Universitas Pendidikan Ganesha Singaraja.

Candiasa. 2010b. Statistik Univariat dan Bivariat Disertai Aplikasi SPSS. Singaraja: Universitas Pendidikan Ganesha.

Departemen Pendidikan Nasional. 2003. Undang-Undang Nomor 20 Tahun 2003. Tentang Sistem Pendidikan Nasional. Jakarta: Depdiknas

Setyosari, Punaji. 2015. Metode Penelitian Pendidikan dan Pengembangan. Jakarta: Prenada Media Group.

Sudijono, Anas. 2013. Pengantar Statistik Pendidikan. Jakarta: PT. Raja Grafindo Persada.

Sugiyono. 2011. Metodologi Penelitian Pendidikan (Pendekatan Kuantitatif, Kualitatif, dan R\&D). Bandung: Alfabeta.

Sugiyono. 2013. Statistika Untuk Penelitian. Bandung: Alfabeta

Trianto. 2010. Mendesain Model Pembelajaran Inovatif-Progresif: Konsep, Landasan, dan Implementasinya pada Kurikulum Tingkat Satuan Pendidikan (KTSP). Jakarta: Kencana Prenada Media Group 